\title{
Agrobacterium-mediated transformation of Jatropha curcas L. with a polyhydroxyalkanoate gene (phaC)
}

\author{
Chesara Novatiano ${ }^{1, *}$, Adi Pancoro ${ }^{2}$, and Erly Marwani ${ }^{2}$ \\ ${ }^{1}$ Biotechnology Study Program, School of Life Sciences and Technology, Institut Teknologi Bandung, Jalan Ganesha No. 10, \\ Bandung 40133, Indonesia \\ ${ }^{2}$ School of Life Sciences and Technology, Institut Teknologi Bandung, Jalan Ganesha No. 10, Bandung 40133, Indonesia \\ *Corresponding author: cnovatiano@gmail.com
}

\begin{abstract}
Polyhydroxybutyrate is a component of bioplastics that is synthesized under the control of enzymes encoded by pha multigenes. The genes are naturally present in Ralstonia eutropha. However, the production of bioplastics in bacteria is inefficient because the bacterial biomass is relatively small compared with plants or fungi. As such, engineering techniques have been developed that enable pha genes to be inserted into plant biomass, and then be expressed in the biomass of the plant to produce polyhydroxybutyrate. The objectives of this study were to transform the tissue of Jatropha curcas using the phaC gene (a pha gene), to regenerate the transformed plant, and to confirm the presence of the inserted genes with PCR. The genetic transformation of J. curcas was mediated by Agrobacterium tumefaciens strain GV3101 containing pARTC by dipping the cotyledon tissue of $J$. curcas in a suspension of the bacterium for $30 \mathrm{~min}$, followed by cocultivation for $3 \mathrm{~d}$ on Murashige and Skoog (MS) medium. The tissue was then placed on a selection medium, i.e. MS medium containing 13.3 $\mu \mathrm{M}$ BAP and $0.05 \mu \mathrm{M}$ IBA with the addition of $20 \mathrm{mg} / \mathrm{L}$ kanamycin. The results showed that $12.35 \%$ of the tissue survived and regenerated into a shoot after 1-2 months. Molecular analysis of the transformed tissue was performed using phaC and nptll primers, in order to detect the presence of the phaC and nptll genes. Specific bands were detected at $659 \mathrm{bp}$ and 700 $\mathrm{bp}$, corresponding to the nptll primer and phaC primer, respectively.
\end{abstract}

KEYWORDS Agrobacterium tumefaciens; bioplastic; Jatropha curcas; nptll; phaC

\section{Introduction}

Bioplastic is a plastic material derived from renewable energy sources of living organisms and is biodegradable. Some of these materials obtained from microbial activity on plant material such as vegetable oil, corn starch and legumes. The main component of bioplastics is polyhydroxybutyrate (PHB) which resemble the components in petroplastics polypropylene.

PHB is a compound derived from polyhydroxyalkanoate (PHA) which is one of renewable resources-based polymers of bioplastic (Reddy et al. 2003). PHB is synthesized from two acetyl coenzim-A in the presence of three enzymes $\beta$-ketothiolase, acetoacetyl-CoA reductase and PHA synthase which encoded by multiple genes of phaA, phaB, phaC, respectively (Lössl et al. 2003). Those three genes are naturally found in bacteria Ralstonia eutropha that responsible in carbon storage (Poirier 2002). Therefore, existing bioplastic industry uses culture of $R$. eutropha to convert sugar plant into PHB.

The PHB production by using culture of bacteria encounters some obstacles, i.e. low productivity and higher cost compared to that production by using petroplastic polypropylene. This because of the bacterial biomass is relatively small. Therefore it is necessary to look for larger organisms that can express the three genes to produce more quantities of PHB. With genetic engineering techniques it is allowed pha genes from $R$. eutropha are isolated and inserted into plant which can then be expressed in the biomass of the plant to produce PHB.

Studies regarding PHB production on transgenic plants has been developed in several plants. Poirier et al. (1992) inserted gene encoding PHB in Arabidopsis thaliana that produced $0.1 \%$ PHB in its dry biomass. Lössl et al. (2003) conducted transformation of PHB-related genes in Nicotiana tabacum which obtained 1.7\% PHB in its dry biomass. A. thaliana was reported to produce $40 \%$ PHB in dry weight of leaves (Bohmert et al. 2002). Moreover, PHB expression as much as $0.36 \%$ was reported in shell of transgenic soy bean seed Schnell et al. (2012).

With regard to the matter discussed above, we were interested to create plants producing bioplastic material by doing genetic transformation that is by inserting PHB genes into plant tissue. One of the good candidates 
plant for this purposes was Jatropha curcas, a non-edible plants producing seeds that belongs to Euphorbiaceae, and widely known to produce oil for biodiesel due to abundant oil content of its seed. J. curcas is unable to produce PHB because it does not have any genes for PHB synthesis. On the other hand, this plant produces a lot of seeds that contain high acetyl-CoA which is responsible as substrate in PHB synthesis, so that $J$. curcas is very suitable to be genetically engineered to contain PHB genes for then to be able to produce PHB in their seed.

Previous study reported the isolation of phaC gene and construction of phaC gene together with nptII gene as marker gene in plant expression vector pARTC (Widhiasi 2011). This vector composed of seed specific promoter LKfCS3, peptide signal ctp, phaC gene and nos terminator, that can be expressed in plants. LKfCS3 seed specific promoter plays a role to promote PHB synhtesis in seed without affecting transgenic plants growth.

There are several reports of $A$. tumefaciens-mediated in J. curcas. Kajikawa et al. (2012) succesfully transformed J. curcas using A. tumefaciens and found the shoot frequency of cotyledon explant was higher than hypocotyl explant. Pan et al. (2010) and Khemkladngoen et al. (2011) also succesfully transformed $J$. curcas using A. tumefaciens with cotyledon explant.

However, there was less report on the transformation of $J$. curcas with PHB genes. Therefore, the objectives of present study were to transform tissue of J. curcas by phaC gene (one of pha genes), to regenerate transformed plant (J. curcas containing phaC gene), and to confirm the presence of inserted genes by PCR technique. Genetic transformation was performed in J. curcas using pARTC vector mediated by $A$. tumefaciens.

\section{Materials and methods}

\subsection{Plant materials}

The explant used in this study was cotyledon obtained from $J$. curcas seed IP-3P aged 7 days. The seeds were obtained from the Research Institute for Tobacco Plant and Fiber, the Plantation Research and Development Center (Balai Penelitian Tanaman Tembakau dan Serat, Pusat Penelitian dan Pengembangan Perkebunan), Bogor, Indonesia. To obtain cotyledon, the seeds were washed with water for $30 \mathrm{~min}$, and further washed with detergent for $30 \mathrm{~min}$, and alcohol $70 \%$ for $5 \mathrm{~min}$. The seeds were peeled and washed with $30 \%$ solution of $5.25 \%$ natrium hypochlorite $(\mathrm{NaClO})$ for $15 \mathrm{~min}$ and $15 \%$ solution of $5.25 \% \mathrm{NaClO}$ for $10 \mathrm{~min}$, and blot-dried on sterile filter paper, were further cut into two pieces vertically and placed in solid free Murashige \& Skoog (MS) medium to allow germination. After $7 \mathrm{~d}$ of incubation, the emerged cotyledons were cut into pieces approximately $1 \mathrm{~cm}$ in size, then planted in pre-culture solid MS medium with $13.3 \mu \mathrm{M}$ BAP and $0.05 \mu \mathrm{M}$ IBA for $3 \mathrm{~d}$, prior to Agrobacteriummediated transformation.

\subsection{Agrobacterium strain, plasmid and culture condi- tions}

The expression vector pARTC (Figure 1) with kanamycin selection and containing phaC cassete (promoter LKfCS3peptide signal ctp-phaC gene-nos terminator) was introduced into A. tumefaciens strain GV3101 and used for stable transformation. A single colony of A. tumefaciens strain GV3101 containing pARTC expression vector was cultured in $5 \mathrm{~mL}$ liquid YEP in addition of rifampisin 25 $\mathrm{mg} / \mathrm{L}$ and kanamycin $50 \mathrm{mg} / \mathrm{L}$. Culture was further planted for $3 \mathrm{~d}$ with agitation of $250 \mathrm{rpm}$, at $25^{\circ} \mathrm{C}$ and dark condition. One percent of liquid culture was replaced to $50 \mathrm{~mL}$ YEP in addition of rifampicin $25 \mathrm{mg} / \mathrm{L}$ and kanamycin 50 $\mathrm{mg} / \mathrm{L}$ to obtain $\mathrm{OD}_{600}=0.6$. Suspension of $A$. tumefaciens was transferred to tube and centrifuged at $4000 \mathrm{rpm}$ for 20 min. Supernatant was removed and pellet of A. tumefaciens was further solved in liquid half-strength MS in ratio 1:3. Suspension was used in A. tumefaciens infection for transformation.

\subsection{Genetic transformation and plant regeneration of J. curcas}

Tranformation by A. tumefaciens was applied into cotyledon explants of $J$. curcas by dipping method. Firstly, cotyledon explants were soaked for $30 \mathrm{~min}$ in suspension of $A$. tumefaciens containing $100 \mu \mathrm{M}$ acetosyringone while shaken at $100 \mathrm{rpm}$. Afterwards, explants were blotdried on sterile paper and planted on cocultivation solid MS medium supplemented with $13.3 \mu \mathrm{M}$ BAP, $0.05 \mu \mathrm{M}$ IBA and $100 \mu \mathrm{M}$ acetosyringone for $3 \mathrm{~d}$ in the dark at approximately $25^{\circ} \mathrm{C}$. The explants werethen washed three times with sterile water for $5 \mathrm{~min}$ and two times with Augmentin ${ }^{\mathrm{TM}} 300 \mathrm{mg} / \mathrm{L}$ solution for $10 \mathrm{~min}$ to eliminate ex-

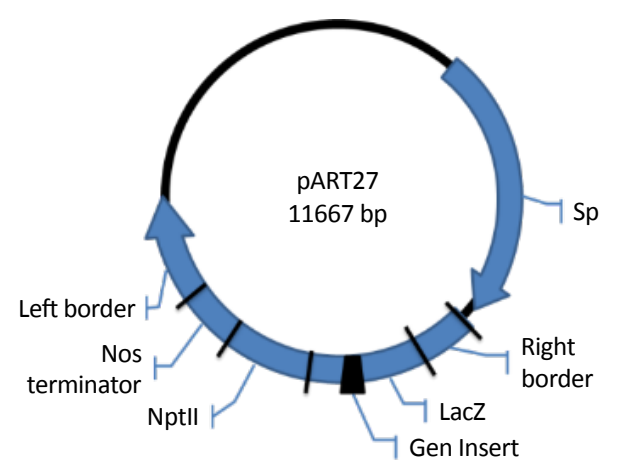

(a)

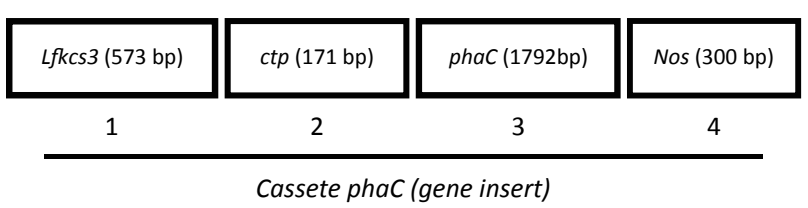

(b)

FIGURE 1 Plasmid pARTC expression vector. (a) pARTC map. (b) cassete of phaC: (1) promoter Lfkcs3 (573 bp); (2) peptide signal ctp (171 bp); (3) phaC gene (1792 bp); (4) terminator nos (300 bp). 
cess of bacteria. Washed explants were blot-dried on sterile paper and transferred to selection medium consisted of solid MS medium supplemented with $13.3 \mu \mathrm{M}$ BAP, 0.05 $\mu \mathrm{M}$ IBA, $300 \mathrm{mg} / \mathrm{L} \mathrm{Augmentin}^{\mathrm{TM}}$ and $20 \mathrm{mg} / \mathrm{L}$ kanamycin according to method of Pan et al. (2010) for 4-8 weeks.

Survived explants were sub-cultured into shoot inducing medium, which consisted of solid MS medium supplemented with $13.3 \mu \mathrm{M}$ BAP, $0.05 \mu \mathrm{M}$ IBA, 150 $\mathrm{mg} / \mathrm{L}$ Augmentin ${ }^{\mathrm{TM}}$ and $20 \mathrm{mg} / \mathrm{L}$ kanamycin. Furthermore, shoots were transferred into elongation medium, which consisted of solid MS medium with $1.0 \mu \mathrm{M}$ IBA and Augmentin $^{\mathrm{TM}} 150.0 \mathrm{mg} / \mathrm{L}$. Shoots were further transferred into rooting medium, a liquid half strength MS medium supplemented with $4.9 \mu \mathrm{M}$ (IBA). All media were adjusted to $\mathrm{pH}$ 5.6-5.8, solidified with $0.8 \%$ (w/v) agar, and autoclaved at $121^{\circ} \mathrm{C}$ for $15 \mathrm{~min}$. Antibiotics were filtersterilized prior to being added into $40-50^{\circ} \mathrm{C}$ cooling autoclaved medium.

\subsection{Molecular analysis of A. tumefaciens colony and transgenic plants}

The presence of nptII and phaC in the T-DNA was examined in colony of $A$. tumefaciens (crude PCR) and putative transformant with nptII and phaC primers. The DNA template of $A$. tumefaciens was obtained by suspending single colony in $10 \mu \mathrm{L}$ sterile deionized water. Whereas genomic DNAs were isolated from shoot of putative transformant and non-transgenic controls using the cetyl trimethylammonium bromide (CTAB) methode (Doyle 1990).

KAPA2G Fast PCR Kit (KAPA Biosystems) used to confirm nptII gene with primer: nptII_reverse (5CCT TAT CCG CAA CTT CTT TAC CTA-3') and nptII_forward (5-ACA CCC AGC CGG CCA CAC AGT CG-3'). The protocol for PCR reaction as follow: initial denaturation of $95^{\circ} \mathrm{C}$ for $3 \mathrm{~min}, 35$ cycles of denaturation at $95^{\circ} \mathrm{C}$ for $15 \mathrm{~s}$, annealing $55^{\circ} \mathrm{C}$ for $15 \mathrm{~s}$, elongation $72^{\circ} \mathrm{C}$ $15 \mathrm{~s}$ and final elongation at $72^{\circ} \mathrm{C}$ for $1 \mathrm{~min}$. Confirmation of phaC was performed with Dream Taq PCR Kit (Thermo Scientific) using phaC_forward (5'-TCT AGA AAC ATG GCG ACC GGC AAA-3') and phaC_reverse (5’-ATC GCG AAG ATC TGA GTC ATG CCT TGG-3’). The protocol included as follow: initial denaturation at $95^{\circ} \mathrm{C}$ for $3 \mathrm{~min}, 30$ cycles of denaturation at $95^{\circ} \mathrm{C}$ for $30 \mathrm{~s}$, annealing $57^{\circ} \mathrm{C}$ for $30 \mathrm{~s}$, elongation $72^{\circ} \mathrm{C}$ for $1 \mathrm{~min}$ and final elongation at $72^{\circ} \mathrm{C}$ for $5 \mathrm{~min}$. PCR amplification products were separated on a $1.0 \%(\mathrm{w} / \mathrm{v})$ agarose gels, stained with ethidium bromide and visualized under UV light.

\section{Results and discussion}

\subsection{Molecular analysis of phaC gene in pARTC plas- mid, nptll, and phaC genes in A. tumefaciens strain GV3101}

The expression vector pARTC commonly used in plants that containing phaC as one of responsible genes in PHB biosynthesis. The presence of phaC in pARTC was ini- tially confirmed prior to its transformation into A. tumefaciens. DNA amplification of pARTC using phaC primer resulted 1700 bp bands on lane 1-5 (Figure 2a) which corresponds to the gen phaC (1792 bp) as reported by Ayudia (2010) and Widhiasi (2011) that phaC gene had 1790s bp. Therefore, it was assumed that pARTC contained phaC, that involve in PHB synthesis. The T-DNA of pARTC was also contained nptII gene, a marker gene for kanamycin resistance. This plasmid was further transformed into $A$. tumefaciens strain GV3101 that used in this experiment as transformation vector in $J$. curcas tissue.

Transformation of pARTC into A. tumefaciens was confirmed using crude PCR with using phaC and nptII as the primers. Crude PCR analysis of A. tumefaciens that had been grown in $50 \mathrm{mg} / \mathrm{L}$ kanamycin by using a pair of nptII primers, resulted 659 bp bands on lane 1-

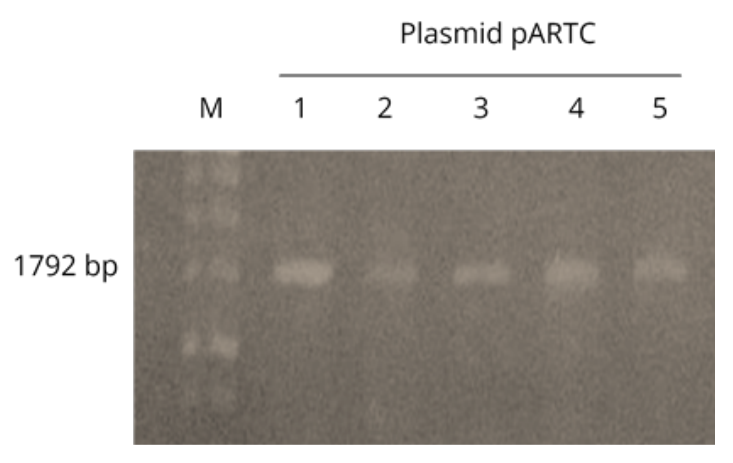

(a)

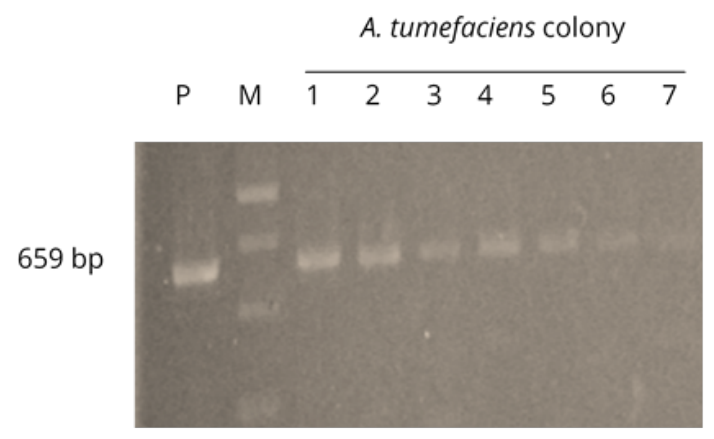

(b)

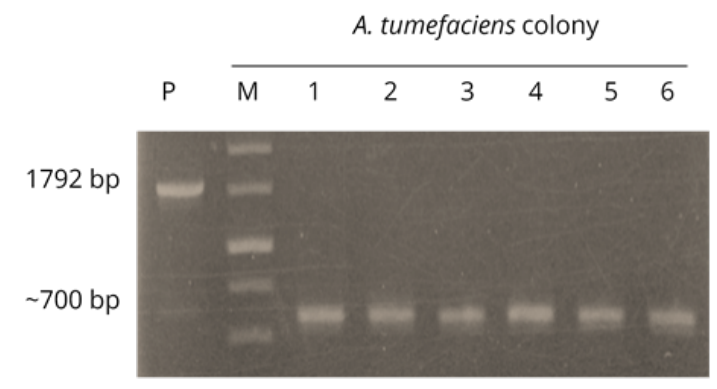

(c)

FIGURE 2 Confirmation the construct of pARTC plasmid. (a) confirmation of phaC gene in pARTC plasmid using phaC primer (lane 1-5); (b) confirmation of nptll gene of Agrobacterium tumefaciens colony using nptll primer (Lane 1-7); (c) confirmation of phaC gene of $A$. tumefaciens colony using phaC primer (Lane 1-6). P is pARTC plasmid as a positive control. $\mathrm{M}=1 \mathrm{~kb}$ DNA marker. 
7 and on lane P (Figure 2b). Lane 1-7 were colonies of A. tumefaciens transformed with pARTC, whereas lane $\mathrm{P}$ was pARTC used as a positive control. The nptII primers used in this study based on nptII primers designed by Khanna et al. (2004) to obtain PCR product of 659 bp. Electrophoregram showed that transformed A. tumefaciens strain GV3101 contained pARTC. The nptII gene was located in T-DNA of pARTC that was inserted to A. tumefaciens GV3101 and the gen was used as screening agent for both bacteria and plants. From this results, it was confirmed that the transformed A. tumefaciens strain GV3101 contained pARTC.

The colony of A. tumefaciens grown in a medium containing $50 \mathrm{mg} / \mathrm{L}$ kanamycin was also confirmed by referring to the presence of phaC using crude PCR with phaC primer. Electrophoregram showed bands 700 bp on lane 1-6 colonies of polyhydroxybutyrate (Figure 2c). Lane P which represent pARTC showed band 1792 bp when using phaC as the primer (Figure 2c). Electrophoregram of A. tumefaciens (lane 1-6, Figure 2c) which use phaC primer showed different results compare to the positive control of pARTC (lane P, Figure 2c). The logical explanation regarding the difference between pARTC (lane $\mathrm{P}$ ) and DNA of transformed A. tumefaciens remains unclear. It might be caused by deletion some segment of DNA when pARTC was inserted into $A$. tumefaciens. To determine the cause of it, it is necessary to analysis the pcr product from genome of $A$. tumefaciens that has been inserted with pARTC carrying phaC gene by DNA sequencing. So that, whether the phaC gene has been completely inserted into T-DNA of A. tumefaciens or not can be determined.

According Bočkor et al. (2013), deletion or insertion can occur in bacteria. For example, the genetic analysis of Eschericia coli shows underlying mechanism in deletion or duplication which involves RecA-dependent and RecA-independent. RecA-dependent relies upon homolog recombination which causes different products of crossing between two DNA, resulting different DNA from its origin. Whereas, RecA-independent can generate error of DNA sequence alignment during replication. Both mechanisms are also found in A. tumefaciens.

\subsection{Regeneration of transformed J. curcas}

Transformed J. curcas could generate callus (Figure 3b) after 2-3 weeks incubation in selection medium, and further developed into shoot (Figure 3c) after 4-6 weeks incubation in shoot-inducing medium, which consisted of solid MS medium supplemented with $13.3 \mu \mathrm{M}$ BAP, 0.05 $\mu$ M IBA, $300 \mathrm{mg} / \mathrm{L}$ Augmentin $^{\mathrm{TM}}$ and $20 \mathrm{mg} / \mathrm{L}$ kanamycin (Pan et al. 2010). These finding indicated that transformed $J$. curcas contained T-DNA which was carried by pARTC plasmid vector. On the other hand, untransformed $J$. curcas slowly underwent death in medium containing kanamycin $20 \mathrm{mg} / \mathrm{L}$, which was indicated by alteration the color tissue to brown color (Figure 3f). This was happened

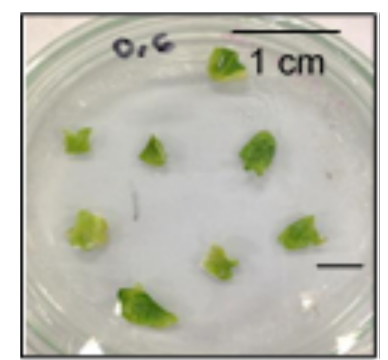

(a)

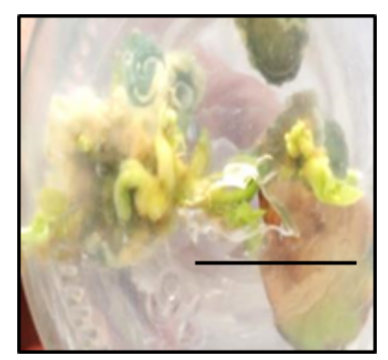

(c)

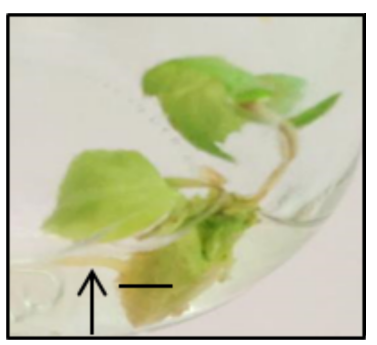

(e)

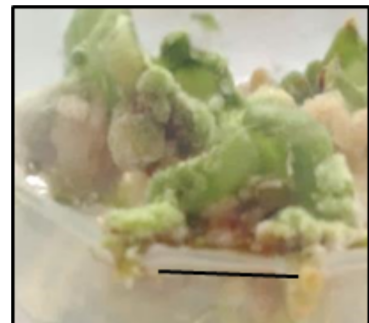

(b)

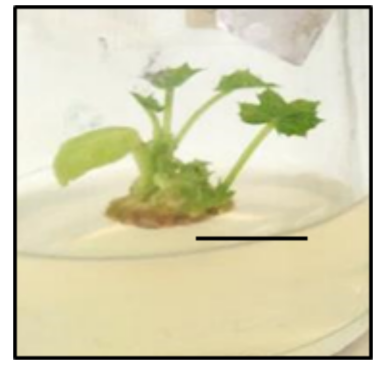

(d)

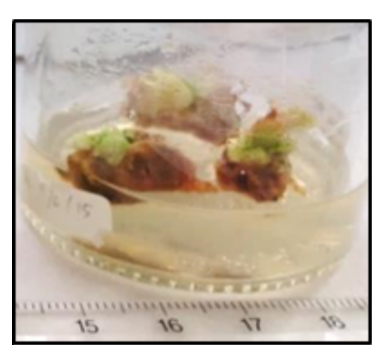

(f)
FIGURE 3 Agrobacterium tumefaciens-mediated transformation and regeneration of Jatropha curcas using cotyledon explants. (a) pre-cultured cotyledon explant; (b) calli induced on selective medium with Augmentin $^{\mathrm{TM}} 300 \mathrm{mg} / \mathrm{L}$ and kanamycin $20 \mathrm{mg} / \mathrm{L}$; (c) shoot induced on selective medium with Augmentin ${ }^{\mathrm{TM}} 300$ $\mathrm{mg} / \mathrm{L}$ and kanamycin $20 \mathrm{mg} / \mathrm{L}$; (d) elongation shoot on elongation medium, which consisted solid MS supplemented with $1 \mu \mathrm{M}$ IBA and $150 \mathrm{mg} / \mathrm{L}$ Augmentin ${ }^{\mathrm{TM}}$ without kanamycin; (e) rooted transgenic plant; (f) untransformed J. curcas on selective medium.

because untransformed tissue did not have nptII gene so that tissue not has resistance to kanamycin.

When shoot was transfered into elongation medium, which consisted of solid MS medium supplemented with $1.0 \mu \mathrm{M} \mathrm{IBA}$ and $150 \mathrm{mg} / \mathrm{L}$ Augmentin ${ }^{\mathrm{TM}}$ but without the addition of kanamycin, the shoots were well elongated (Figure 3d) and when the elongated shoots were transferred on root inducing-medium, which consisted liquid half-strength MS supplemented with $4.9 \mu \mathrm{M}$ IBA and 150 $\mathrm{mg} / \mathrm{L}$ Augmentin ${ }^{\mathrm{TM}}$, the plantlet of J. curcas was regenerated (Figure 3e). In this experiment, from two replications of transformation using 70 and 80 explants, percentage of $J$. curcas that able to generate shoots resistant to kanamycin was $12.35 \%$ (Table 1).

In this study, seen that regeneration of $J$. curcas from Agrobacterium-mediated transformation was obtained with indirect organogenesis, that was through cal- 
TABLE 1 Percentage of Jatropha curcas transformation to form shoot.

\begin{tabular}{lccc}
\hline Replication & $\begin{array}{l}\text { Transformed } \\
\text { explants }\end{array}$ & $\begin{array}{l}\text { Regenerated } \\
\text { explants forming } \\
\text { shoot in kanamycin } \\
\text { selective medium }\end{array}$ & $\begin{array}{l}\text { Percentage } \\
\text { (\%) }\end{array}$ \\
\hline I & 70 & 8 & 11.40 \\
II & 60 & 8 & 13.30 \\
Average & & & 12.35 \\
\hline
\end{tabular}

lus formation followed by shoot formation. The growth factors used, BAP and IBA, were responsible in the shoot regeneration. As reported by Khemkladngoen et al. (2011) that $13.3 \mu \mathrm{M}$ BAP and $0.5 \mu \mathrm{M}$ IBA could promote callus formation followed by shoot formation in J. curcas with growth effieciency as much as $78 \%$.

Rooting induction of transformed $J$. curcas was rather difficult to be obtained, but nevertheless was successfully obtained when using liquid half-strenght MS with $4.9 \mu \mathrm{M}$ IBA (Figure 3e). Similar finding was also reported by Toppo et al. (2012) and Kajikawa et al. (2012) that the use of indole butiric acid (IBA) as a growth factor gave a better result in the induction of root than indole acetic acid (IAA) as an endogenous auxin. Auxin induces root fomation by breaking root apical dominance through cytokinins.

Success rate was measured based on ratio between number of explants regenerated to shoot in selective medium and number of explants initially planted. Transformation of $J$. curcas was conducted in two repetitions using A. tumefaciens strain GV3101 with $\mathrm{OD}_{600}=0.6$ and soaked for $30 \mathrm{~min}$. The average frequencies of J. curcas to generate shoot resistant to kanamycin in this study was $12.35 \%$ (Table 1), which was lower than the results obtained by Kumar et al. (2010), 29\%, by using a similar bacterial density $\left(\mathrm{OD}_{600}=0.6\right)$. Kumar et al. (2010) conducted transformation of $J$. curcas mediated by different A. tumefaciens strain, i.e. LBA 4404. The different used of strain of bacteria in this study might caused the lower frequencies of transformation.

\subsection{Confirmation of J. curcas putative transformant using PCR method}

The presences of nptII and phaC on J. curcas putative transformants were detected with PCR using nptII and phaC primers. The PCR product of $J$. curcas putative transformant using nptII primer was 659 bp (Figure 4a), indicating the integration of $n p t I I$ in the $J$. curcas genome. Neomycin phosphotransferase II (nptII) gene plays a role to inactivated antibiotic from amino-glycosylated group such as kanamycin, genitisin and neomycin. The nptII gene is located in T-DNA as selective agent for transformed J. curcas.

PCR amplified DNA of $J$. curcas putative transformant using phaC primer was 700 bp (Figure 4b), as well as band of $A$. tumefaciens confirmed by using phaC primer (Figure 2c) to contain phaC gene. It indicates that phaC gene of the T-DNA of $A$. tumefaciens was integrated in plant genome. Thus, tranformation in this study took place accordingly. Yet, it does not confirm the presence of phaC (1792 bp) in tranformed plants genome by the A. tumefaciens. This might be due to the deletion or insertion in integration of T-DNA in A. tumefaciens. Further analysis is therefore needed, such as sequencing of PCR products using phaC primer.

Confirmation of $J$. curcas putative transformant using nptII primer, showed nptII was integrated in J. curcas genome, indicated by band of 659 bp in accordance with positive control, pARTC. On the other hand, untransformed J. curcas not indicate the presence of nptII. Confirmation of J. curcas putative transformant using phaC primer obtained band of $700 \mathrm{bp}$ as well as A. tumefaciens (Figure $4 \mathrm{~b}$ ), yet it was different than result obtained from pARTC amplification using phaC primer. Untransformed $J$. curcas that confirmed using phaC primer also not obtained, indicating the absence of phaC. It might be caused by deletion of phaC in A. tumefaciens which may occurr during integration to plant genome.

Confirmation of $J$. curcas putative transformant using nptII primer, showed nptII was integrated in J. curcas genome, indicated by band of 659 bp in accordance

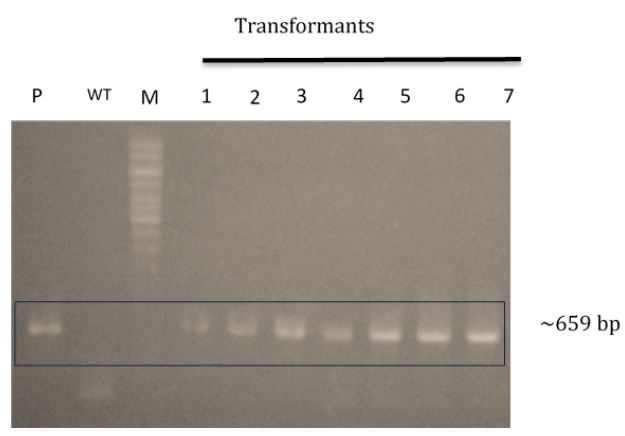

(a)

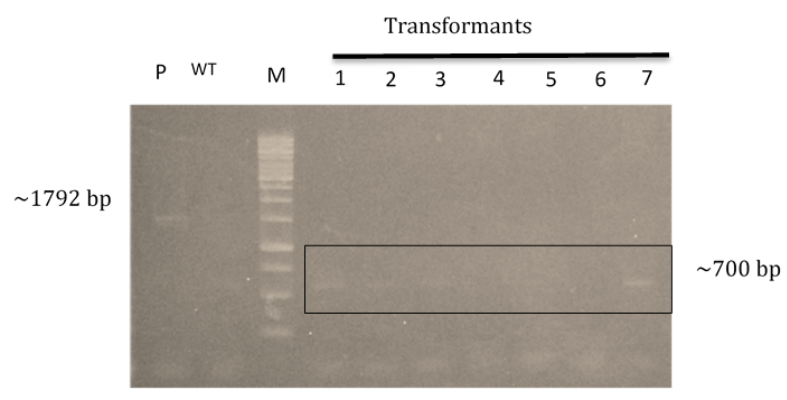

(b)

FIGURE 4 Molecular analysis of Jatropha curcas putative transformant by PCR method. (a) PCR analysis for detection nptll gene using primer nptll; (b) PCR analysis for detection phaC gene using primer phaC. Lanes $M=1 \mathrm{~kb}$ DNA marker gene. $\mathrm{P}=$ positive control (plasmid pARTC), $\mathrm{WT}=$ negative control (untransformed J. curcas), Lanes 1-7 = J. curcas putative transformants. 
with positive control, pARTC. On the other hand, untransformed J. curcas not indicate the presence of nptII. Confirmation of $J$. curcas putative transformant using phaC primer obtained band of $700 \mathrm{bp}$ as well as A. tumefaciens (Figure $4 \mathrm{~b}$ ), yet it was different than result obtained from pARTC amplification using phaC primer. Untransformed $J$. curcas that confirmed using phaC primer also not obtained, indicating the absence of phaC. It might be caused by deletion of phaC in A. tumefaciens which may occur during integration to plant genome.

Deletion or insertion can occurs during T-DNA integration to plant genome. Integration of T-DNA in plant genome remains elusive. Although T-DNA is believed to integrate to plant genome via DNA double stranded breaks (DSB) repair. Underlying mechanism of DNA double stranded breaks (DSB) repair in plants involve nonhomolog end joining (NHEJ). The presence of DSB will promote T-DNA binding to DSB, and later repaired via NHEJ. In this pathway, DNA repair is conducted without homolog sequence and directly ligated, usually followed by deletion or insertion on T-DNA (Tzfira 2003). Referring to study done by Tzfira (2003), plants encountering DSB induced by UV have higher number of integrated T-DNA compared to plants without induction. However, there was only $0.81 \%$ plants had completely integrated by T-DNA. Deletion was also detected in $1.13 \%$ plants, the rest was T-DNA integrated by deleted sequence on some base, or insertion during integration to plants genome (Tzfira 2003).

\section{Conclusions}

In conclusion, the cotyledon tissue of J. curcas was successfully transformed by A. tumefaciens GV3101 carrying pARTC plasmid vector that contain $n p t I I$ gene $(659 \mathrm{bp}$ ) for being resistance to kanamycin antibiotics and regenerate callus on selection medium. The putative transgenic callus was differentiated to form microshoot on Murashige \& Skoog medium with addition of $13.3 \mu \mathrm{M}$ BAP and $0.5 \mu \mathrm{M}$ IBA. Rooting of the microshoot was obtained when the shoot was transferred on liquid half-strenght MS with 4.9 $\mu \mathrm{M}$ IBA to produce planlet. Molecular anaysis of the planlet indicated the presence of $n p t I I$ gene (659 bp). However, the presence of phaC gene (1792 bp) that is for synthesis of a component of bioplastic, polyhydroxybutirate, remain unclear. So that, further analysis of identified bands 700 bp which was estimated as a part of phaC (1796 bp) is required, such as DNA sequencing of PCR products by using phaC primer and southern blot analysis in order to confirm the presence of phaC gene sequence.

\section{Acknowledgments}

The authors gratefully acknowledge Dr. Adi Pancoro (School of Life Sciences and Technology, Institut Teknologi Bandung) for providing the pARTC vector. The research was supported by the academic scholarship, the
Directorate of Higher Education, the Ministry of Education and Culture, Republic of Indonesia through the Graduate School of Institut Teknologi Bandung, number 1414.60/E4.4/2013 awarded to Chesara Novatiano.

\section{Authors' contributions}

EM, AP, CN designed the study. CN carried out the laboratory work. CN, EM, AP analyzed the data. CN, EM wrote the manuscript. All authors read and approved the final version of the manuscript.

\section{Competing interests}

The authors declare no competing interest.

\section{References}

Ayudia D. 2010. Konstruksi vektor ekspresi-spesifik biji tanaman untuk ekspresi gen phaA, phaB dan phaC pengkode enzim pensintesis biomaterial polihidroksibutirat (PHB). [Master's thesis]. [Bandung, Indonesia]: Biotechnology Graduate Program-Institut Teknologi Bandung.

Bohmert K, Balbo I, Steinbüchel A, Tischendorf G, Willmitzer L. 2002. Constitutive expression of the beta-ketothiolase gene in transgenic plants: a major obstacle for obtaining polyhydroxybutyrateproducing plants. Plant Physiol. 128(4):1282-1290. doi:10.1104/pp.010615.

Bočkor L, Jelenić† S, Malenica, Mlinarec J, Besendorfer V, Ivančić-Baće I. 2013. Comparison of intraplasmid rearrangements in Agrobacterium tumefaciens and Escherichia coli. Food Technol Biotechnol. 51(4):441445.

Doyle J. 1990. Isolation of plant DNA from fresh tissue. Focus 12:13-15.

Kajikawa M, Morikawa K, Inoue M, Widyastuti U, Suharsono S, Yokota A, Akashi K. 2012. Establishment of bispyribac selection protocols for Agrobacterium tumefaciens- and Agrobacterium rhizogenesmediated transformation of the oil seed plant Jatropha curcas L. Plant Biotechnol. 29(2):145-153. doi:10.5511/plantbiotechnology.12.0406b.

Khanna H, Becker D, Kleidon J, Dale J. 2004. Centrifugation Agrobacterium tumefaciens-mediated transformation (CAAT) of embryogenic cell suspensions of banana (Musa spp. Cavendish AAA and Lady finger AAB). Mol Breed. 14(3):239-252. doi:10.1023/B:MOLB.0000047771.34186.e8.

Khemkladngoen N, Cartagena JA, Fukui K. 2011. Physical wounding-assisted Agrobacterium-mediated transformation of juvenile cotyledons of a biodieselproducing plant, Jatropha curcas L. Plant Biotechnol Rep. 5(3):235-243. doi:10.1007/s11816-011-0177-0.

Kumar N, Vijay Anand K, Pamidimarri DS, Sarkar T, Reddy MP, Radhakrishnan T, Kaul T, Reddy 
M, Sopori SK. 2010. Stable genetic transformation of Jatropha curcas via Agrobacterium tumefaciens-mediated gene transfer using leaf explants. Ind Crops Prod. 32(1):41-47. doi:10.1016/j.indcrop.2010.03.002.

Lössl A, Eibl C, Harloff HJ, Jung C, Koop HU. 2003. Polyester synthesis in transplastomic tobacco (Nicotiana tabacum L.): significant contents of polyhydroxybutyrate are associated with growth reduction. Plant Cell Rep. 21(9):891-899. doi:10.1007/s00299-0030610-0.

Pan J, Fu Q, Xu ZF. 2010. Agrobacterium tumefaciensmediated transformation of biofuel plant Jatropha curcas using kanamycin selection. Afr J Biotechnol. 9(39):6477-6481.

Poirier Y. 2002. Polyhydroxyalknoate synthesis in plants as a tool for biotechnology and basic studies of lipid metabolism. Prog Lipid Res. 41(2):131-155. doi:10.1016/S0163-7827(01)00018-2.

Poirier Y, Dennis DE, Klomparens K, Somerville C. 1992. Polyhydroxybutyrate, a biodegradable thermoplastic, produced in transgenic plants. Science 256(5056):520-523. doi:10.1126/science.256.5056.520.

Reddy CSK, Ghai R, Kalia V. 2003. Polyhydroxyalkanoates: an overview. Bioresour Technol. 87(2):137146.

Schnell JA, Treyvaud-Amiguet V, Arnason JT, Johnson DA. 2012. Expression of polyhydroxybutyric acid as a model for metabolic engineering of soybean seed coats. Transgenic Res. 21(4):895-899. doi:10.1007/s11248-011-9575-X.

Toppo DD, Singh G, Purshottam DK, Misra P. 2012. Improved in vitro rooting and acclimatization of Jatropha curcas plantlets. Biomass Bioenergy 44(Supplement C):42-46. doi:10.1016/j.biombioe.2012.04.014.

Tzfira T. 2003. Site-specific integration of Agrobacterium tumefaciens T-DNA via double-stranded intermediates. Plant Physiol. 133(3):1011-1023. doi:10.1104/pp.103.032128.

Widhiasi P. 2011. Konstruksi multigen pengkode enzim pensintesis polihidroksibutirat (PHB) dalam vektor ekspresi tanaman PART. [Master's thesis]. [Bandung, Indonesia]: Biotechnology Graduate ProgramInstitut Teknologi Bandung. 